\title{
Volcaniclastic sediments from mid-oceanic Kolbeinsey Ridge, north of Iceland: Evidence for submarine volcanic fragmentation processes
}

\author{
Klas S. Lackschewitz \\ Jonathan Dehn \\ Hans-Joachim Wallrabe-Adams D-24148 Kiel, Germany
}

\begin{abstract}
Volcaniclastic sediments of the active Kolbeinsey Ridge, north of Iceland, reflect changing fragmentation mechanisms due to increasing sea level during the last deglaciation. Glass shards deposited on the western flank of the mid-oceanic ridge before $13.4 \mathrm{ka}$ are vesicular $(20 \%-60 \%)$, whereas shards deposited since $13.4 \mathrm{ka}$ are mostly vesicle free and of hyaloclastic origin. The vesicle-rich shards display morphology thought to be atypical for submarine eruptions at this depth $(400-500 \mathrm{~m})$. The environmental conditions during the deposition of these layers (regional ice cover, more than $200 \mathrm{~km}$ from the nearest subaerial source) preclude a subaerial origin for these shards. We propose an eruption mechanism in which hot vesiculating bombs from a low-energy eruption are transported upward through the water column by convection. These particles reach their volcanic fragmentation depth (VFD) and undergo secondary fragmentation, creating the vesicle-rich shards recovered near the ridge. Rising sea level since the end of the last glaciation was sufficient to prevent the erupted particles from reaching the VFD, thus ending the formation of vesicle-rich shards. This model explains the presence of vesicular shards in sediments of mid-oceanic ridges where no subaerial source can be inferred.
\end{abstract}

\section{INTRODUCTION}

The volcanic deposits of the mid-oceanic ridges are of increasing interest because of their contribution to the deep ocean's sedimentary record. Submarine volcanism often produces large quantities of volcaniclastic particles that become dispersed in basins adjacent to the volcanic sources. These tephra layers can provide important local stratigraphic markers because they represent virtual instants in geologic time (Kennett, 1981).

In this paper we present data on the composition and texture of volcanic particles in sediments from the southern region of the mid-oceanic Kolbeinsey Ridge collected during RV Poseidon cruise 158/1 (core 0020) in 1989 and 175/2 (core 1171) in 1990, in an attempt to relate the submarine fragmentation processes to paleoclimatic history. We describe and discuss sedimentological, geochemical, and climatic changes from two cores of the western flank of the Kolbeinsey Ridge (Fig. 1).

The southern Kolbeinsey Ridge is the section of the Mid-Atlantic Ridge north of Iceland from about lat $66^{\circ} \mathrm{N}$ extending northward to the Spar fracture zone near $69^{\circ} \mathrm{N}$. The ridge is characterized by a rift valley grading northward into a sharp crest (Lackschewitz and Wallrabe-Adams, 1991). The ridge emerges above sea level at Kolbeinsey Island where basaltic rocks are exposed (Saemundsson and Sigurdarson, 1987). The southern Kolbeinsey Ridge is a ridge segment inferred to be recently active from the freshness of basalts and the presence of hydrothermal activity. The submarine basalts and brown volcaniclastic glass particles in the sediments show characteristics of mid-oceanic ridge basalts (Lackschewitz and WallrabeAdams, 1991; Devey et al., 1994). This area has been extensively cored, and the recovered sediments were described by Lackschewitz
(1991) and Mienert and Wallrabe-Adams (1992). Today the study area is characterized by cold polar water masses on which an ice sheet forms in winter.

\section{METHODS}

This research is based on a detailed microscopic and scanning electron microscope (SEM) study. Chemical analyses were performed by electron microprobe at the Mineralogical Institute of Kiel University, Germany (minimum three measurements per sample). Age control is based on oxygen isotope stratigraphy (determination by the Institute of Nuclear Physics of Kiel University) and ${ }^{14} \mathrm{C}$ atomic mass spectroscopy dating on four samples (determination by Eidgenössische Technische Hochschule, Zürich). The particle shapes of individual glass shards was measured with a VIDS IV semiautomatic image analysis system. The vesicles were individually measured for single glass particles in SEM photographs.

\section{COMPOSITION AND DISTRIBUTION OF VOLCANICLASTIC SEDIMENTS}

Core 0020 was collected on the western flank of the southern Kolbeinsey Ridge $\sim 8 \mathrm{~km}$ from the ridge axis (Fig. 1). Coring recovered $2.7 \mathrm{~m}$ of sediment in a water depth of $858 \mathrm{~m}$. The recovered

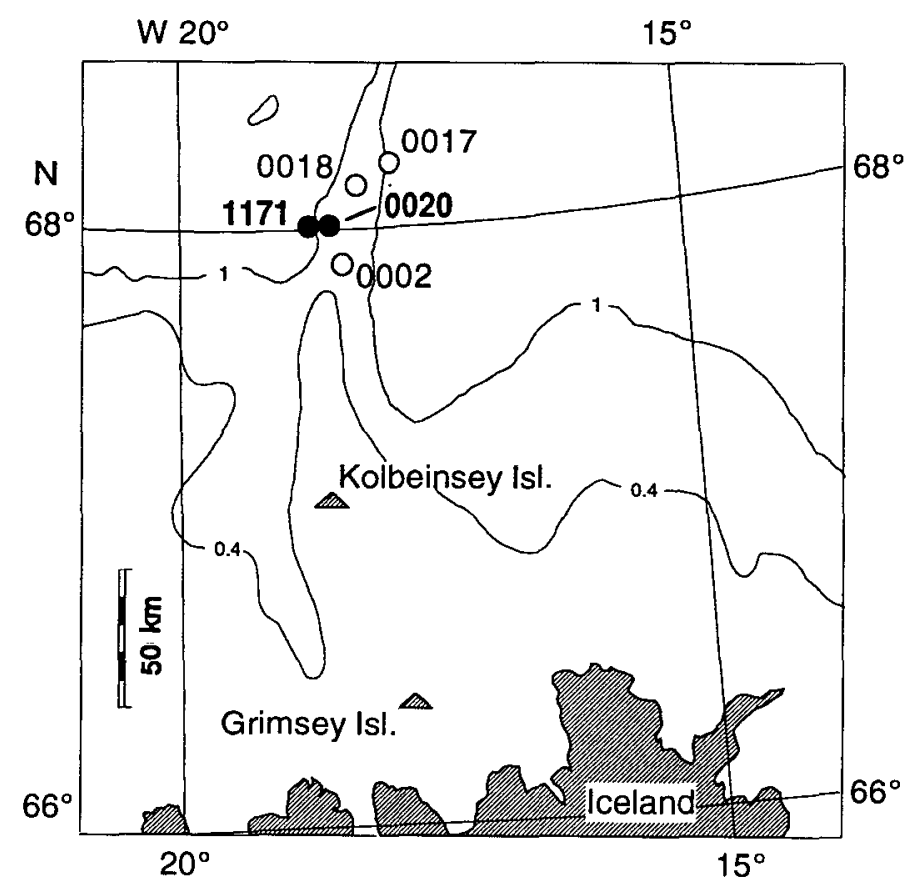

Figure 1. Map showing southern Kolbeinsey Ridge and locations of cores 0020 and 1171 (solid circles) discussed in text. Locations of cores 0002, 0018, and 0017 (shaded circles) from Lackschewitz (1991). Contours in kilometres depth. 
sediments consist mainly of volcanigenic olive-gray sandy, silty clay with some brownish lenses (centimetres to decimetres in size) of sandy material. No lamination or graded bedding is visible. The sediment is composed of $20 \%-60 \%$ basaltic components (Lackschewitz, 1991).

The coarse fraction $(0.063-0.5 \mathrm{~mm})$ of the bulk sediment is composed of volcanic glass $(20 \%-85 \%)$ and biogenic and terrigenous components. This ash consists mostly $(>90 \%)$ of brown glass. The dark to light brown volcanic glasses range in shape and texture from blocky, nonvesicular shards to crenate, highly vesicular, pumiceous types (Fig. 2). Colorless glass (bubble wall shards) is an additional but rare constituent. This clear high-silica glass is a background component common in nearly all marine sediments (Kennett, 1981).

Core 1171 was sampled farther from the mid-ocean ridge about $5 \mathrm{~km}$ west of core 0020 at $935 \mathrm{~m}$ depth (Fig. 1). Only the uppermost metre of the total $2.7 \mathrm{~m}$ recovery consists of fine olive-gray volcanigenic sediments. The volcanic glass component in the coarse fraction of this section is $20 \%-50 \%$, and the glass shards resemble those in core 0020 . The remaining $1.7 \mathrm{~m}$ consists of yellowish-brown clayey silt.

Two morphological types of brown glass are distinguished: (1) blocky, splintery shards and (2) crenate, vesicular forms. The relation of these different shard types in the coarse fraction is shown in Figure 2 . Due to the better resolution provided by the high sedimentation rate (up to $60 \mathrm{~cm} / \mathrm{ka}$ ) in relation to core 1171 , core 0020 is used to characterize the changes in glass morphology and composition with time.

The oxygen isotope record from $270-130 \mathrm{~cm}$ core depth of core $0020(20.7-14.9 \mathrm{ka})$ shows the highest (isotopically heavier) $\delta^{18} \mathrm{O}$ values representing the last glacial period. During this time interval the most dominant volcanic component was vesicular glass $(47 \%$ to $80 \%$ of grains). Radiocarbon-dated samples (core 0020, $17.6 \mathrm{ka}$; core $1171,18.2 \mathrm{ka}$ ) mark the last glacial maximum. According to Vogelsang (1990), the beginning of the last deglaciation (termina- tion IA) is characterized by the rapid transition to low $\delta^{18} \mathrm{O}$ values at $14.9 \mathrm{ka}$, indicating major ice melting. Our radiocarbon data from core 0020 show that the first phase of major melting was completed at $13.4 \mathrm{ka}$. After this time, a drastic increase in the sedimentation of blocky volcanic glass in relation to vesicular shards coincided with a rise in sea level (Fig. 2). From $13.4 \mathrm{ka}$ to the top of the core, blocky shards increase to around $95 \%$ of grains. The same relation is seen in the data from core $\mathbf{1 1 7 1 .}$

Representative chemical analyses of volcanic glass shards from eight depths show normal mid-ocean ridge tholeiitic composition (Table $1^{1}$ ). The maximum water content of these basalts should not exceed $0.3 \%$ by weight (Schilling et al., 1983). Although chemical composition of particles at the individual core depths shows variation in the mean values of the major elements (Fig. 2), statistically significant change in chemical composition of the major elements occurs between 80 and $40 \mathrm{~cm}$ core depth (12.9-12.3 ka). The mean $\mathrm{MgO}$ value decreases from $7.7 \%$ to $6.4 \%$ by weight. The $\mathrm{SiO}_{2}$ contents of the glasses do not adhere to this pattern, however, and range from $52.65 \%$ to $49.56 \%$ by weight throughout the core.

\section{DISCUSSION AND CONCLUSIONS}

Submarine volcaniclastic deposits can be formed through effusive and explosive submarine and subaerial eruptions. Whether submarine eruptions are effusive or explosive depends primarily on water depth, the composition of the magma, the proportion and nature of volatile gases it contains, and the extent of the interaction between magma and water (McBirney, 1963; Fisher and Schmincke, 1984).

Glass-shard form is an important indicator of the type of eruption and eruption environment (e.g., Kokelaar, 1983, 1986;

${ }^{1}$ GSA Data Repository item 9444, Table 1, Average Chemical Composition of Core 00200 Glasses Used in This Study, is available on request from Documents Secretary, GSA, P.O. Box 9140, Boulder, CO 80301.

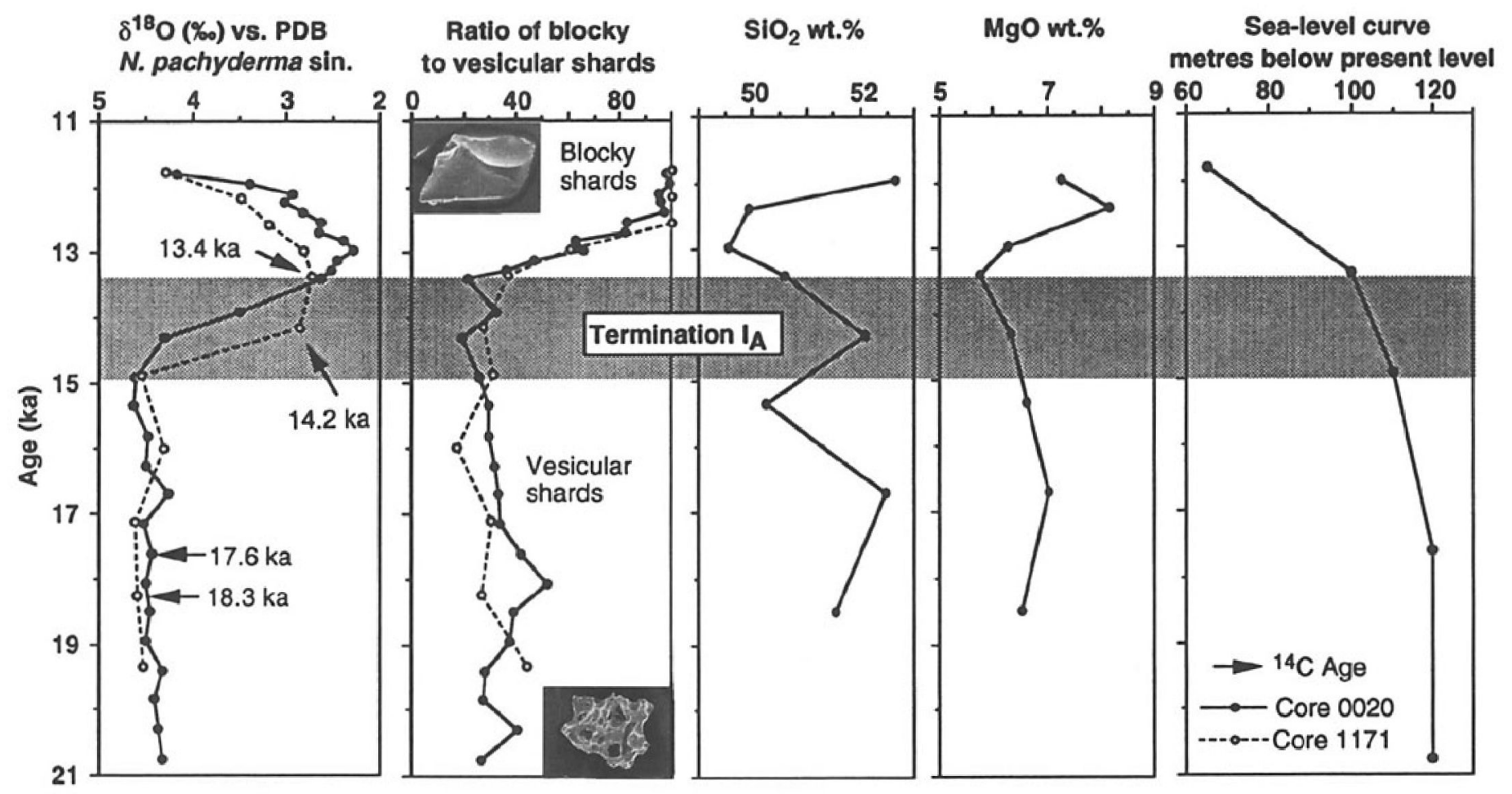

Figure 2. Comparison of oxygen isotope records, down-core distribution of blocky and vesicular shards (covering period $20.7-11.8$ ka in cores 0020 and 1171) including scanning electron photomicrographs of these typical shard forms (length is $300 \mu \mathrm{m}$ ), SiO ${ }_{2}$ and $\mathrm{MgO} \mathrm{contents}$ of basaltic glass shards (core 0020), and estimated sea-level curve (after Fairbanks, 1989). Shading indicates first step of last deglaciation, termination IA (for explanation see text). PDB-Peedee belemnite. 
Heiken and Wohletz, 1985). The changing character of the recovered glass shards shows that either the environment and/or eruption mechanism of the volcaniclastic sediments at Kolbeinsey Ridge changed with time. The older shards are vesicular, showing morphology typical to that of shallow-water or subaerial eruptions (Fig. 2; Kokelaar, 1983; Heiken and Wohletz, 1985). The youngest shards in the sequence tend toward vesicle-free blocky forms characteristic of hyaloclastites formed by submarine lava flows (Rittmann, 1962; Honnorez and Kirst, 1975). These shards are also found in surface sediments at sites 0002 and 0018 from the ridge axis (Lackschewitz, 1991; Fig. 1), providing further support for a hyaloclastic origin and recent volcanic activity. All of the shards have sharp angular surfaces, suggesting a minimum of mechanical erosion due to transport. In addition, the $\delta^{18} \mathrm{O}$ isotope curve and ${ }^{14} \mathrm{C}$ data show no disturbances, excluding emplacement by turbidity currents. Transport distances for the shards were estimated by the method of Dehn (1992) based on particle shape, density, paleowater depth, and approximated currents. The estimated transport distances of all the shards do not exceed $11 \mathrm{~km}$ and average $3.5 \mathrm{~km}$, suggesting a local source for the tephra, presumably the ridge axis. This applies well for the younger hyaloclastites. The calculated submarine transport distances of the vesicular shards are not sufficient for the particles to have originated from the $>200-\mathrm{km}$-distant subaerial sources, Iceland or Jan Mayen. The current Kolbeinsey Island, $\sim 100 \mathrm{~km}$ distant, was formed at $10 \mathrm{ka}$ by volcanic activity on the ridge (Saemundsson and Sigurdarson, 1987), well after the sediments in this study were deposited. Paleodepth calculations show that the area under study was well below sea level $(\sim 500 \mathrm{~m})$ at this time (Lackschewitz, 1991).

Subaerial transport of the vesicular shards would have widely dispersed the tephra, covering several sites where no correlating basaltic material was recovered, such as in core 0017 (Fig. 1). Furthermore, such dispersion requires a large volume of material in order to create discrete tephra layers, particularly in an area with such high sedimentation rates. Such large volumes are atypical for explosive basaltic eruptions (Simkin et al., 1981). The ocean surface in this region had at least seasonal, likely permanent, ice cover at this time (Baumann et al., 1993), so subaerially erupted particles could not have reached the ocean floor. We conclude therefore that all the volcaniclastic materials recovered in these cores are of submarine origin.

Numerous investigations have shown that the vesicularity of lava decreases with increasing water depth (Moore, 1979; Moore and Schilling, 1973) and can be used as an approximate depth indicator. However, vesicularity also changes with chemical composition. Alkalic basalts can be more vesicular than tholeiitic basalts erupted at the same depth (Staudigel and Schmincke, 1984). The recovered glass shards have little compositional variation. When comparing shard form to the composition of the magmas, no correlation is seen (Fig. 2). The magmatic viscosity of the basalts shows no significant change within these compositions $\left(\sim 2 \times 10^{6}\right.$ poise $\left[10^{-3} \mathrm{~N} \mathrm{~s} / \mathrm{m}^{2}\right]$ dependent on temperature; after Shaw, 1972). This suggests that the fragmentation processes in the eruptions were not affected by changes in the magma composition.

A correlation is observed between the sea-level curve and shard form (Fig. 2) in which blocky, vesicle-poor shards become more common with rising sea level. The vesicle-rich shards were formed when the active spreading zone in the vicinity of site 0020 lay at $400-500 \mathrm{~m}$ depth, $120 \mathrm{~m}$ higher than at present $(500-600 \mathrm{~m}$; Mienert and Wallrabe-Adams, 1992). The volcanic fragmentation depth (VFD; Fisher and Schmincke, 1984) is described as the maximum depth at which explosive fragmentation can occur. This level has been estimated at 200 to $>1000 \mathrm{~m}$ depending on magma composition, volatile content, and temperature (see Kokelaar, 1986). Koke- laar also noted that the transition to fragmental deposits for basaltic magma occurs at depths no greater than $100-200 \mathrm{~m}$, whereas McBirney (1963) estimated a depth of $500 \mathrm{~m}$. It is apparent that the VFD depends on many factors and should not be thought of as a fixed depth, but rather as a zone in which fragmentation can occur. Nevertheless, the high vesicularity of the shards in core 0020 cannot be explained by basaltic eruption at a relatively great water depth $(400-500 \mathrm{~m})$. This is supported by the fact that the increase in volume of water in the phase change to steam at this depth interval, though high ( $\sim 10 \%$ increase; McBirney, 1963), does not seem to be enough to create finely spaced pipe vesicles and particles with up to $60 \%$ vesicularity. The following questions arise: How can such vesicle-rich particles be formed underwater; what mechanisms are involved; and what conditions are required?

Fiske and Matsuda (1964) postulated the formation of a submarine eruption cloud that collapsed, forming submarine ash flows in the Tokiwa Formation of Japan. Such an eruption column would lift particles to shallower depths and rapidly decreasing pressure conditions. It is likely that a basaltic eruption, with its high temperature, would create a convection cell capable of transporting particles several centimetres in size to shallower depths and the VFD (Fig. 3A). It has been observed that basaltic bombs vesiculate after ejection and deposition from the vent (Heiken and Wohletz, 1991). The longer a bomb can hold its heat, the longer it can vesiculate (Walker, 1969). Thermal diffusion calculations for these magmas show that a particle of $10 \mathrm{~cm}$ diameter, erupted at $1000^{\circ} \mathrm{C}$, builds a crust and holds an internal temperature of more than $700^{\circ} \mathrm{C}$ for $>1$ min. Initial low-energy fragmentation, i.e., the bursting of a large bubble or flow over a steep or rough surface, would create shreds and blebs of lava. These blebs, in turn, contain smaller vesicles and continue to vesiculate until cooled or until the supply of volatile material is exhausted. Ejection and convection are capable of placing hot, expanding bombs above their individual VFDs. With the rapidly decreasing pressure at this depth, the specific volume of steam increases exponentially (McBirney, 1963). The volume of a vesicle formed at $500 \mathrm{~m}$ and transported to $200 \mathrm{~m}$ depth would increase by $\sim 70 \%$. Accordingly, any vesicles within the bomb would also undergo a volume or resultant pressure increase, producing secondary fragmentation and shattering the bomb into smaller fragments. The depth at which this fragmentation occurs is also dependent on the bomb's geometry. Particles from a single eruption, with identical composition but different size and shape, will fragment at varying depths as they are carried upward in the eruption cell.

The different shard forms observed on the Kolbeinsey Ridge are the result of changing eruptive environment, eruptive mechanics, or a combination of both. An eruption with a low effusion rate cannot eject particles with high velocities, whereas a high effusion rate would develop an eruption column, easily transporting particles to shallower water depths. A change in volatile content also affects the energy of the eruption and the ejection of particles. Such changes, however, are often associated with changes in magma composition that are not present in the Kolbeinsey basaltic glasses. Such change in eruption mechanics could also be the result of a change in vent geometry, for which there is also no evidence, particularly for such a short time interval and low spreading rate (half rate $<1$ $\mathrm{cm} / \mathrm{yr}$ ). The eruption mechanisms were probably similar for all of the tephra recovered, indicating that the controlling factor in shard form was environmental. The change in the shard types with time (after $13.4 \mathrm{ka}$ ) is a result of the change in depth of the ridge and the transport of vesiculating bombs above the VFD (Fig. 3). Between 20 and $13.4 \mathrm{ka}$, when the sea level was 100 to $120 \mathrm{~m}$ lower than it is today (Fairbanks, 1989), the central ridge axis lay at a depth of 400 to $500 \mathrm{~m}$. Eruption produced blocky shards as well as more com- 


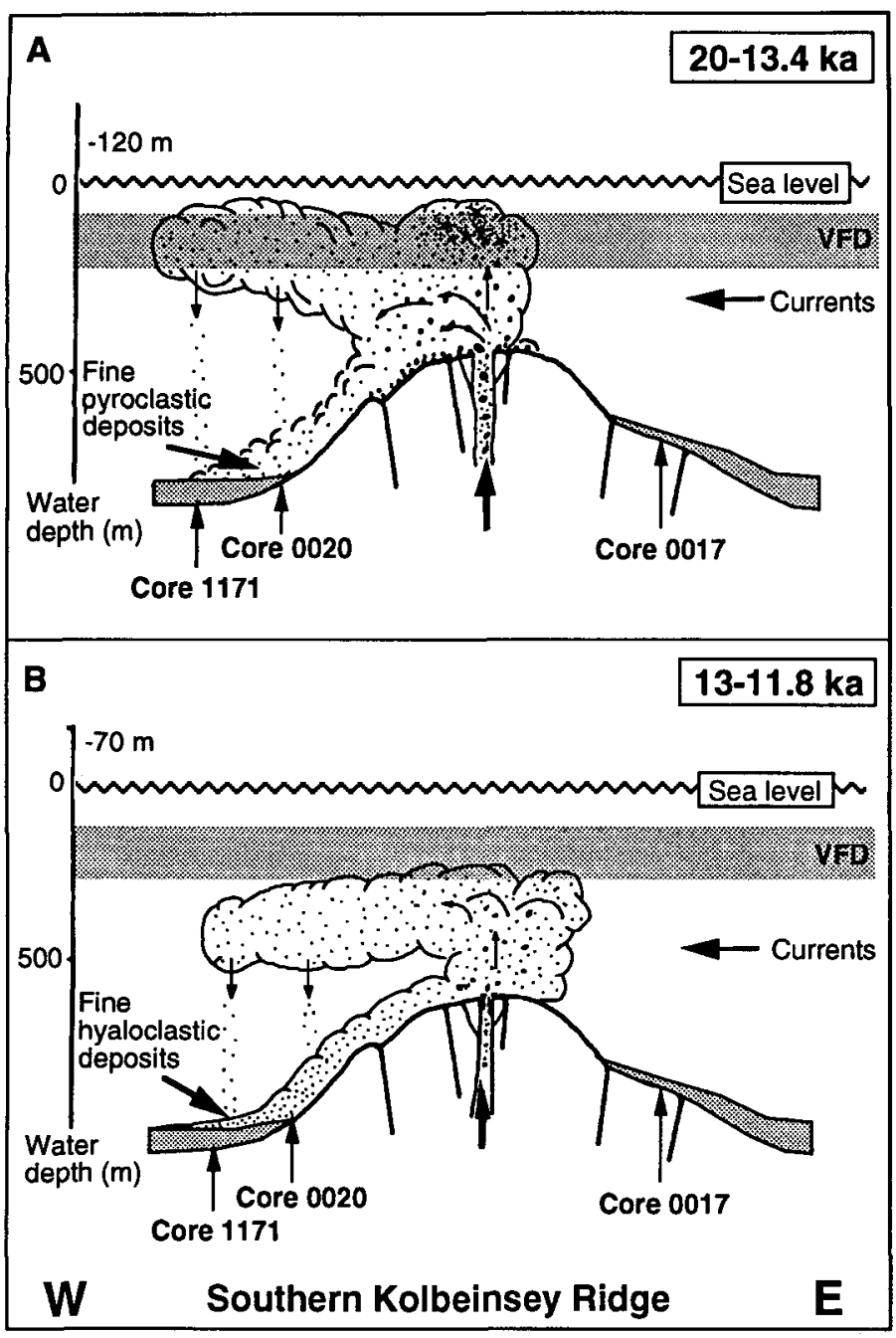

Figure 3. Schematic model of submarine volcanic fragmentation changes during last glaciation-deglaciation. A: Between 20 and 13.4 ka, submarine eruption cloud, causing convective transport of hot vesiculating particles, in concert with low sea level $(120 \mathrm{~m}$ below present level), permits bombs to reach their volcanic fragmentation depth (VFD). Here bombs fragmented, in part exposively, due to decreasing pressure, thus producing vesicular shards. Local water-current activity led to higher accumulation of shards on western flank of Kolbeinsey Ridge. B: From 13 to $11.8 \mathrm{ka}$, sea level rose (up to $70 \mathrm{~m}$ below present level), and most erupted particles were not able to reach their VFD. Production of vesicular shards waned in favor of blocky shards formed by hyaloclastic processes.

plicated shard forms. Vesiculating bombs from the low-energy eruption were transported upward by convection, where they underwent expansion and secondary high-energy fragmentation. This produced the atypical submarine shard forms, which then settled to the ocean floor under the influence of local currents (Fig. 3A). After $13.4 \mathrm{ka}$ the sea level rose sharply after termination IA. With the increasing depth, erupted particles were no longer able to reach the VFD and undergo secondary fragmentation. The resulting tephra deposits are primarily composed (<90\%) of blocky shards (Fig. 3B).

This study shows that the diversity of tephra shards formed on mid-ocean ridges is greater than previously imagined. It also suggests that many submarine tephra layers thought to contain subaerially formed glass shards need not contain any subaerial material whatsoever and may be wholly of submarine origin.

\section{ACKNOWLEDGMENTS}

We thank $\mathrm{H}$. Cordt and $\mathrm{H}$. Erlenkeuser for carrying out mass spectrometric measurements; W. Wölfli of Eidgenössische Technische Hochschule,
Zürich, for determining and providing atomic mass spectroscopy ${ }^{14} \mathrm{C}$ data; U. Schuldt for photographic assistance; R. Mühe, H.-U. Schmincke, and R. Werner for helpful comments; and R. Cas and T. Pierson for helpful reviews. This investigation forms part of the research project "Der GrönlandSchottland Rücken," funded by the Bundesministerium für Forschung und Technologie (MFG 00664).

\section{REFERENCES CITED}

Baumann, K. -H., Lackschewitz, K. S., Erlenkeuser, E., Henrich, R., and Jünger, B., 1993, Late Quaternary carbonate sedimentation and terrigenous input along the East Greenland continental margin: Marine Geology, v. 114, p. 13-35.

Dehn, J., 1992, Volcanic evolution of the eastern Indian Ocean: Broken Ridge and Ninetyeast Ridge, ODP Leg 121 [Ph.D. thesis]: Kiel, Germany, Kiel University, $73 \mathrm{p}$.

Devey, C. W., Garbe-Schönberg, D., Stoffers, P., Chauvel, P., and Mertz, D. F., 1994, Chemical effects of dynamic melting beneath ridges: Reconciling major and trace element variations in Kolbeinsey (and global) MORB: Journal of Geophysical Research, v. 99, p. 9077-9095.

Fairbanks, R. G., 1989, A 17,000-year glacio-eustatic sea level record: Influence of glacial melting rates on the Younger Dryas event and deepocean circulation: Nature, v. 143, p. 637-642.

Fisher, R. V., and Schmincke, H. -U., 1984, Pyroclastic rocks: BerlinHeidelberg-New York, Springer-Verlag, $472 \mathrm{p}$.

Fiske, S. R., and Matzuda, T., 1964, Submarine equivalents of ash flows in the Tokiwa Formation, Japan: American Journal of Science, v. 262, p. $76-106$.

Heiken, G., and Wohletz, K., 1985, Volcanic ash: Berkeley, University of California Press, $246 \mathrm{p}$.

Heiken, G., and Wohletz, K., 1991, Fragmentation processes in explosive volcanic eruptions, in Fisher, R. V., and Smith, G. A., eds., Sedimentation in volcanic settings: SEPM Special Publication 45, p. 19-26.

Honnorez, J., and Kirst, P., 1975, Submarine basaltic volcanism: Morphometric parameters for discriminating hyaloclastites from hyalotuffs: Bulletin Volcanologique, v. 39, p. 1-25.

Kennett, J. P., 1981, Marine tephrochronology, in Emiliani, C., ed., The sea: The oceanic lithosphere (Volume 7): Chicago, Wiley, p. 1373-1436.

Kokelaar, B. P., 1983, The mechanism of Surtseyan volcanism: Geological Society of London Journal, v. 140, p. 939-944

Kokelaar, B. P., 1986, Magma-water interactions in subaquaous and emergent basaltic volcanism: Bulletin of Volcanology, v. 48, p. 275-289.

Lackschewitz, K. S., 1991, Sedimentationsprozesse am aktiven mittelozeanischen Kolbeinsey Rücken (N'Island): Geomar Report, v. 9, 133 p.

Lackschewitz, K. S., and Wallrabe-Adams, H. -J., 1991, Composition and origin of sediments on the mid-oceanic Kolbeinsey Ridge, north of Iceland: Marine Geology, v. 101, p. 71-82.

McBirney, A. R., 1963, Factors governing the nature of submarine volcanism: Bulletin Volcanologique, v. 26, p. 455-469.

Mienert, J., and Wallrabe-Adams, H. -J., 1992, FS Poseidon Expedition 175: Geomar Report, v. 11, p. 1-56.

Moore, J. G., 1979, Vesicularity and $\mathrm{CO}_{2}$ in mid-ocean ridge basalt: Nature, v. 282 , p. $250-253$.

Moore, J. G., and Schilling, J. G., 1973, Vesicles, water, and sulfur in Reykjanes Ridge basalts: Contributions to Mineralogy and Petrology, v. 41, p. 105-118.

Rittmann, A., 1962, Volcanoes and their activity: New York, Wiley, p. 188. Saemundsson, K., and Sigurdarson, S., 1987, Kolbeinsey: Ægir, v. 80, p. 2-12. Schilling, J. G., Zajac, M., Evans, R., Johnston, T., White, W., Devine, J. D., and Kingsley, R., 1983, Petrologic and geochemical variations along the Mid-Atlantic Ridge from $29^{\circ} \mathrm{N}$ to $73^{\circ} \mathrm{N}$ : American Journal of Science, v. 283 , p. $510-586$

Shaw, H. R., 1972, Viscosities of magmatic silicate liquids: An empirical method of prediction: American Journal of Science, v. 272, p. 870-893.

Simkin, T., Siebert, L., McClelland, L., Bridge, D., Newhall, C., and Latter, J. H., 1981, Volcanoes of the world: Stroudsburg, Pennsylvania, Hutchinson and Ross, p. 232.

Staudigel, H., and Schmincke, H. -U., 1984, The Pliocene seamount series of La Palma/Canary Islands: Journal of Geophysical Research, v. 89, p. $11,195-11,215$.

Vogelsang, E., 1990, Paläo-Ozeanographie des Europäischen Nordmeeres an Hand stabiler Kohlenstoff- und Sauerstoffisotope: Berichte aus dem Sonderforschungsbereich 313, v. 23, 136 p.

Walker, G. P. L., 1969, The breaking of magma: Geological Magazine, v. 106, p. $166-173$.

Manuscript received May 5, 1994

Revised manuscript received July 27, 1994

Manuscript accepted August 10, 1994 


\section{Geology}

\section{Volcaniclastic sediments from mid-oceanic Kolbeinsey Ridge, north of Iceland: Evidence for submarine volcanic fragmentation processes}

Klas S. Lackschewitz, Jonathan Dehn and Hans-Joachim Wallrabe-Adams

Geology 1994;22;975-978

doi: 10.1130/0091-7613(1994)022<0975:VSFMOK>2.3.CO;2

\section{Email alerting services}

\section{Subscribe}

Permission request click www.gsapubs.org/cgi/alerts to receive free e-mail alerts when new articles cite this article

click www.gsapubs.org/subscriptions/ to subscribe to Geology

click http://www.geosociety.org/pubs/copyrt.htm\#gsa to contact GSA

Copyright not claimed on content prepared wholly by U.S. government employees within scope of their employment. Individual scientists are hereby granted permission, without fees or further requests to GSA, to use a single figure, a single table, and/or a brief paragraph of text in subsequent works and to make unlimited copies of items in GSA's journals for noncommercial use in classrooms to further education and science. This file may not be posted to any Web site, but authors may post the abstracts only of their articles on their own or their organization's Web site providing the posting includes a reference to the article's full citation. GSA provides this and other forums for the presentation of diverse opinions and positions by scientists worldwide, regardless of their race, citizenship, gender, religion, or political viewpoint. Opinions presented in this publication do not reflect official positions of the Society.

Notes

Geological Society of America

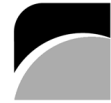

THE

GEOLOGICAL

SOCIETY

OF AMERICA 